\title{
Analysis of the Globose Basal Cell Compartment in Rat Olfactory Epithelium Using GBC-1, a New Monoclonal Antibody against Globose Basal Cells
}

\author{
Bradley J. Goldstein and James E. Schwob \\ Department of Anatomy and Cell Biology and Clinical Olfactory Research Center, SUNY Health Science Center, \\ Syracuse, New York 13210
}

The olfactory epithelium (OE) supports ongoing neurogenesis throughout life and regenerates after experimental injury. Although evidence indicates that proliferative cells within the population of globose (light) basal cells (GBCs) give rise to new neurons, little is known about the biology of GBCs. Because GBCs have been identifiable only by an absence of staining with reagents that mark other cell types in the epithelium, we undertook to isolate antibodies that specifically react against GBCs and to characterize the GBC compartment in normal and regenerating $O E$. Monoclonal antibodies were produced using mice immunized with regenerating rat $O E$, and a monoclonal antibody designated GBC-1, which reacts against GBCs of the rat $O E$, was isolated. In immunohistochemical analyses, antibody GBC-1 was found to label GBCs in both normal and regenerating $O E$ as we are currently able to define them: basal cells that incorporate the mitotic tracer bromodeoxyuridine and

The adult mammalian olfactory epithelium (OE) supports ongoing neurogenesis throughout life and retains the capacity to regenerate both neurons and the non-neuronal cell populations after experimental injury (Schultz, 1941; Moulton et al., 1970; Graziadei and Monti Griziadei, 1979; Monti Graziadei and Graziadei, 1979; Costanzo and Graziadei, 1983; Schwob et al., 1995). As in other systems capable of renewal and regeneration, such as the intestinal epithelium (Potten and Hendry, 1983), the epidermis (Morris and Potten, 1994), and the hematopoietic system (Heimfeld and Weissman, 1991), so-called stem cells capable of self-replacement and of eventually giving rise to all mature cell types most likely also exist in the $\mathrm{OE}$ to support its continual turnover and its recovery after direct injury. Several lines of evidence have demonstrated that cells of the globose (light) basal cell (GBC) compartment proliferate and give rise to neurons in normal epithelium or after bulbectomy (Graziadei and Monti Graziadei, 1979; Calof and Chikaraishi, 1989; Schwartz Levey et al., 1991, 1992; Caggiano et al., 1994; Schwob et al., 1994a). Moreover, the direct destruction of both neurons and sustentacular cells induced by methyl bromide ( $\mathrm{MeBr}$ ) inhalation (Schwob et al., 1995 ) activates a precursor cell that is capable of giving rise to both

Received Dec. 1, 1995; revised March 21, 1996; accepted March 28, 1996.

This work was supported by Grants K04 DC 00080 and R01 DC 02167 from National Institutes of Health and an American Heart Association medical student fellowship (B.J.G.). We thank Drs. Jon Covault, Anthony Frankfurter, and Karina Meiri for their generosity in supplying us with antibodies. We also thank Renee Mezza for able technical assistance and Dr. George Ring for his comments.

Correspondence should be addressed to Dr. James E. Schwob, Department of Anatomy and Cell Biology, SUNY Health Science Center, 750 East Adams Street, Syracuse, NY 13210.

Copyright (C) 1996 Society for Neuroscience $0270-6474 / 96 / 164005-12 \$ 05.00 / 0$ fail to express cytokeratins or neural cell adhesion molecule. During epithelial reconstitution after direct experimental injury with methyl bromide, expression of the GBC- 1 antigen overlaps to a limited extent with expression of cell-specific markers for horizontal basal cells, Bowman's gland and sustentacular cells, and neurons. These data suggest that GBC-1 may mark multipotent cells residing in the GBC compartment, which are prominent during regeneration. However, a limited number of cells in the regenerating $O E$ with other phenotypic characteristics of GBCs lack expression of the GBC-1 antigen. GBC-1 has revealed novel aspects of GBC biology and will be useful for studying the process of olfactory neurogenesis.

Key words: stem cells; sustentacular cells; neurogenesis; epithelial reconstitution; differentiation-state marker; olfactory bulb ablation neurons and sustentacular cells, as shown by retroviral labeling studies (Schwob et al., 1994a). Because this type of direct epithelial damage spares many GBCs, it is possible that the presumptive stem cells reside within the basal cell compartment. However, there are no definitive markers for GBCs with which the basal cell compartment can be studied. Thus, GBCs generally have been defined by an absence of staining with other cell-specific markers and by their incorporation of mitotic tracers (Graziadei and Monti Graziadei, 1979; Calof and Chikaraishi, 1989; Schwob et al., 1995). Therefore, many questions remain regarding GBC biology. For instance, are there biochemically and/or functionally heterogeneous subpopulations within this compartment? Do stem cells, capable of self-renewal and of giving rise to all cell types of the $\mathrm{OE}$, reside within the GBC compartment, or are all GBCs committed neuronal precursors? Answers to such questions will contribute to our understanding of neurogenesis in the $\mathrm{OE}$.

In an effort to characterize the GBC compartment, we have generated a mouse monoclonal antibody, GBC-1, that recognizes GBCs. The present study describes the characterization of the GBC compartment of the adult rat OE using GBC-1 and other cell-specific markers. We have examined this cell compartment in normal epithelium and in epithelium undergoing the reconstitution that follows injury induced experimentally by olfactory bulb ablation or $\mathrm{MeBr}$ exposure.

\section{MATERIALS AND METHODS}

Animals. Male Sprague-Dawley rats and female Balb/c mice were obtained from Taconic Farms (Germantown, NY) and maintained in a heatand humidity-controlled vivarium on ad libitum food and water. Rats 
(150-250 gm) were lesioned by exposure to $330 \mathrm{ppm} \mathrm{MeBr}$ gas for $6 \mathrm{hr}$, as described previously (Schwob et al., 1995). Other rats were lesioned by ablation of their right olfactory bulb after induction of surgical anesthesia via intramuscular injection of a cocktail of ketamine and acepromazine (10 and $0.05 \mathrm{mg}$ per $100 \mathrm{gm}$ body weight, respectively), as described previously (Schwob et al., 1992). At selected time points after $\mathrm{MeBr}$ cxposure or olfactory bulb ablation, rats were anesthetized decply by intraperitoneal injection of $100 \mathrm{mg} / \mathrm{kg}$ sodium pentobarbital and killed by perfusion intracardially with PBS followed by periodate-lysine and $0.75 \%$ paraformaldehyde (PLP) in phosphate buffer, $\mathrm{pH}$ 7.4. One hour before perfusion, all animals were injected intravenously with $100 \mathrm{mg} / \mathrm{kg}$ 5-bromodeoxyuridine (BrdU) to permit the identification of proliferating cells, as described previously (Schwob et al., 1995). Mice were killed by cervical dislocation. All animal-use protocols were approved by the Committee for Humane Use of Animals at the SUNY Health Science Center (Syracuse, NY).

Monoclonal antibody production. Balb/c mice were immunized with olfactory epithelial cells obtained from rats $7 \mathrm{~d}$ after $\mathrm{MeBr}$ lesion. To prepare the immunogen, rats were overdosed with sodium pentobarbital and perfused with PBS, and the nasal septum and turbinate bones were isolated and dissociated enzymatically with papain (Worthington Biochemical, Freehold, NJ). Dissociated cells were suspended in adjuvant (RIBI ImmunoChem, Hamilton, MT) and injected intraperitoneally into mice. One month later, mice were boosted with the same material. After an additional month, mice were given a final boost consisting of cells without adjuvant.

Four days after the final immunization, mouse splenocytes were fused with NS-1 myeloma cells (Harlow and Lane, 1988). After cervical dislocation, the spleen was removed aseptically and dissociated mechanically in serum-free medium. Splenocytes were fused with myeloma cells using polyethylene glycol (PEG 4000, Gibco, Grand Island, NY). Then cells were distributed into 96-well culture plates in hypoxanthine, aminopterin, and thymidine (HAT)-selective (Gibco) medium and incubated at $37^{\circ} \mathrm{C}$ in $5 \% \mathrm{CO}_{2}$. Hybridoma supernatants were screened immunohistochemically on sections of OE from rats killed $4 \mathrm{~d}$ after lesion, as described below. Selected hybridomas, including GBC-1 and the sustenacular cell-specific marker SUS-4, were cloned twice by limiting dilution.

Tissue preparation. Sections for screening and further characterization were generated from rats killed 2, 3, 4, 5, 7, 10, or $14 \mathrm{~d}$ after $\mathrm{MeBr}$ lesion or $4 \mathbf{d}$ after olfactory bulbectomy or from unlesioned control animals. After perfusion with fixative, the nasal septum and turbinate bones were separated from the surrounding tissue and decalcified in saturated EDTA (Sigma, St. Louis, MO) at $\mathrm{pH} 7.0$, cryoprotected with $30 \%$ sucrose, embedded in O.C.T. compound (Tissue-Tek, Miles, Elkhart, IN), and frozen in liquid nitrogen. The tissue was cryosectioned coronally at $\leq 8 \mu \mathrm{m}$.

Antibody reagents. Monoclonal antibodies GBC-1 and SUS-4 were produced in our laboratory. Polyclonal anti-neural cell adhesion molecule (NCAM) was the generous gift of Dr. Jonathan Covault (Covault and Sanes, 1986). Monoclonal antibody 10E8 against growth-associated protein-43 (GAP-43) was the generous gift of Dr. Karina Meiri (Meiri et al., 1991). Monoclonal antibody TuJ-1 against neuron-specific $\beta$-tubulin was the generous gift of Dr. Anthony Frankfurter (Moody et al., 1987; Lee and Pixley, 1994). The $\mathrm{I} \boldsymbol{\beta}_{4}$ isolectin from Bandeiraea simplicifolia (BS-I) (Holbrook et al., 1995) and polyclonal anti-BS-I were obtained commercially (Vector Laboratories, Burlingame, CA). Monoclonal antibodies G3G4 against BrdU and 151-8AE4 against the rat epidermal growth factor receptor $(\alpha \mathrm{EGFr})$ were obtained from the Developmental Studies Hybridoma Bank (University of Iowa, Iowa City, IA). Secondary and tertiary reagents were purchased from Vector Laboratories or Jackson ImmunoResearch (West Grove, PA). The mouse Ig isotyping kit was purchased from Sigma.

Immunohistochemistry. The procedures for fuorescent immunostaining and peroxidase-based immunostaining with a single primary antibody were described previously (Schwob et al., 1992, 1994b). For hybridoma screening, undiluted culture supernatants were applied to the tissue sections. Bound antibodies were visualized by incubation with biotinylated horse anti-mouse antibodies followed by fluoresceinated streptavidin. Sections were examined with a Nikon Microphot FX microscope equipped with a B-2E, G-1A, UV-1A (all three from Nikon), and combined FITC/Texas Red (Chromega, Burlington, VT) epifluorescent filters.

GBC-1 was combined with other reagents in double or triple immunofluorescent staining. After being blocked in PBS containing $4 \%$ bovine serum albumin (BSA) and 10\% normal horse serum, sections were incubated with GBC-1 ascites diluted 1:500 in the blocking solution, visualized with fluoresceinated streptavidin as above, and then cycled through another round of staining with other markers. When anti-BrdU was used as the second label, the sections were treated after ( $B B C-1$ staining with a graded series of ethanol followed by $6 \mathrm{~N} \mathrm{HCl}$. The sections were neutralized by washing in $0.1 \mathrm{M}$ sodium borate at $\mathrm{pH} 8.5$, rinsed in PBS, and then blocked. Subsequently, the tissue was incubated with monoclonal antibody G3G4, which was visualized with Texas Redconjugated donkey anti-mouse IgG.

Peroxidase-based staining with GBC-1 using dianninobenzidine (DAB) as the chromogen was also combined with immunofluorescent staining using one of a set of other markers, including BS-I, anti-NCAM, 151$8 \mathrm{AE} 4$, and/or TuJ-1, subsequent to the GBC-1 staining. BS-I was visualized with goat anti-BS-I and a Texas Red-conjugated secondary antibody. Anti-NCAM, TuJ-1, and 151-8AE4 were visualized using appropriate biotinylated secondary antibodies and fluoresceinated streptavidin. In other cases, staining with GBC-1 was visualized using $\mathrm{DAB}$ as the chromogen, and then the tissue was cycled through a second round of staining with anti-NCAM, visualized using the SG substrate kit (Vector Laboratories).

Double immunofluorescent staining with GBC- 1 and SUS-4 using classspecific secondary reagents. Monoclonal antibodies GBC-1 and SUS-4 were isotyped by ELISA (Harlow and Lane, 1988). Briefly, immunoplates were coated with anti-mouse Ig antibodies prepared in goat that react with specific mouse Ig isotypes. Then wells were incubated with GBC-1, SUS-4, or controls. Bound antibody was visualized with biotinylated horse anti-mouse Ig (nonspecific for heavy and light chains), followed by avidin-biotinylated horseradish peroxidase and DAB.

We took advantage of the finding that GBC-1 and SUS-4 are different Ig classes (see Results) to combine these monoclonal antibodies in double immunofluorescent staining using class-specific secondary antibodies. After they were blocked, tissue sections were incubated in a combination of GBC-1 ascites diluted 1:300 and SUS-4 culture supernatant diluted $1: 10$ in the blocking solution. After they were washed, sections were incubated in a solution containing a $\mu$ chain-specific, Texas Red-conjugated goat anti-mouse IgM and $\gamma$ chain-specific, biotinylated horse anti-mouse IgG secondary antibodies. Then the slides were washed again and incubated with fluoresceinated streptavidin. In some cases, adjacent sections were stained simultaneously with BS-I and anti-NCAM, as described above. After completion of the immunofluorescent staining, slides were immersed in bis-benzimide (Hoechst 33258, Polysciences, Warrington, PA) to label the nuclei.

\section{RESULTS}

\section{The isolation of monoclonal antibody GBC-1}

The monoclonal antibody GBC-1 was isolated first by its staining of many cells in $\mathrm{OE}$ lesioned by exposure to $\mathrm{MeBr}$ gas $4 \mathrm{~d}$ before perfusion. At this time the reconstituting epithelium contains mostly cells with the characteristics of GBCs (as we are currently able to define them): proliferating, non-neuronal, nonhorizontal basal cell (HBC), and nonsustentacular cells. In immunohistochemical terms, most of the cells in 4-d-lesioned epithelium do not express detectable levels of NCAM, cytokeratin 5, or cytokeratin 18 immunoreactivity, which are markers for neurons, HBCs, and sustentacular cells, respectively (Schwob, 1992; Schwob et al., 1994b, 1995).

In addition to $\mathrm{GBC}-1$, we isolated a monoclonal antibody during the screening process, which we designated SUS-4 in keeping with the nomenclature of Hempstead and Morgan (1985), that specifically stains sustentacular cells and cells of Bowman's glands and ducts (Fig. 1). By ELISA, we determined that GBC-1 is an IgM with $\kappa$ light chain, and SUS-4 is an $\operatorname{IgG}_{1}$ with $\kappa$ light chain (data not shown).

\section{Monoclonal antibody GBC-1 recognizes GBCs}

That GBC-1 labels bona fide GBCs is demonstrated by several lines of evidence. GBCs are defined as cytokeratin (-)/NCAM $(-) / B r d U(+)$ cells (Fig. 1) (Schwob et al., 1992). In the normal $\mathrm{OE}$ of adult rats, GBC-1-labeled cells are distributed patchily in 

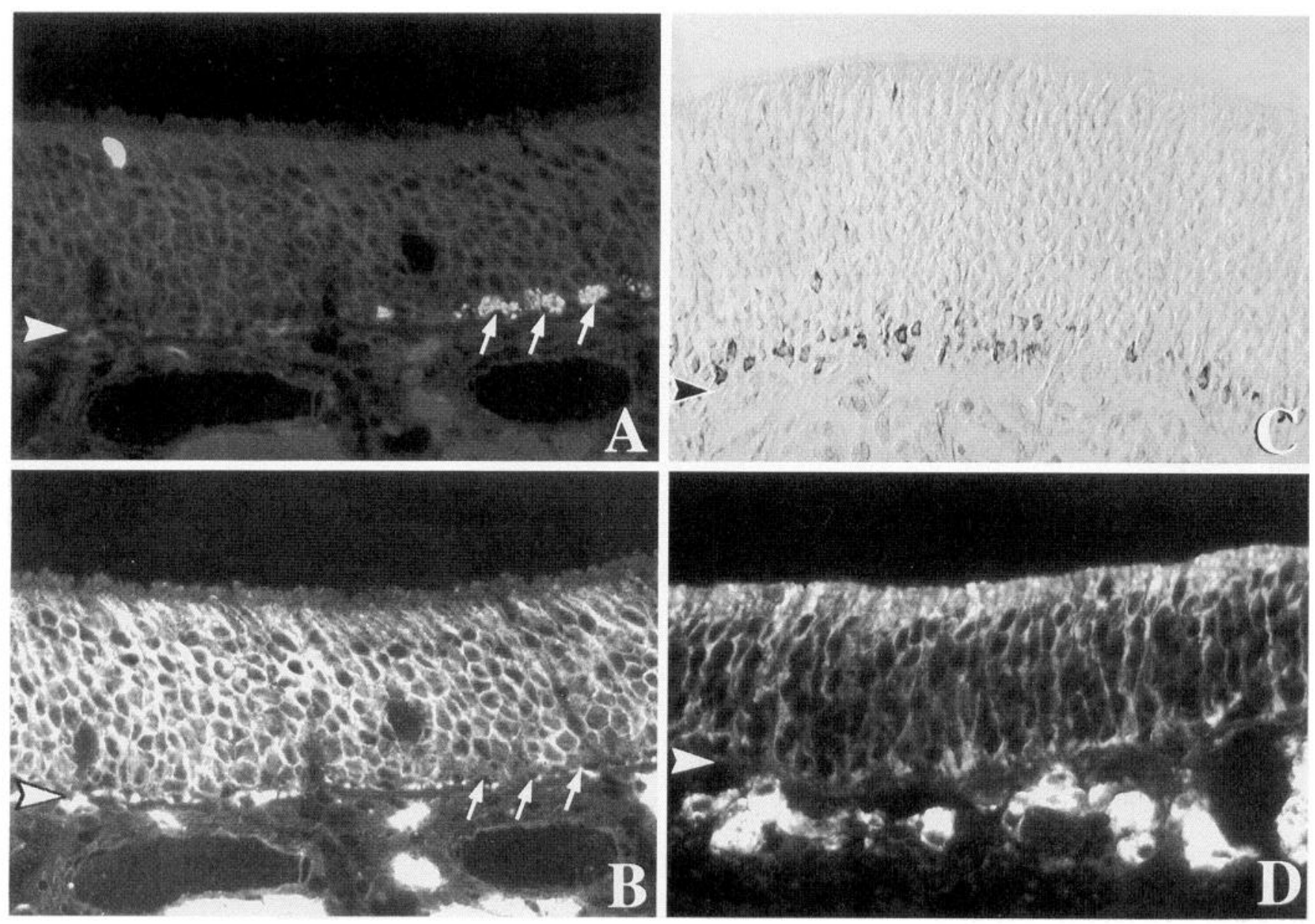

Figure 1. Monoclonal antibody GBC-1 labels GBCs. GBCs are defined as mitotically active (BrdU-incorporating) basal cells that lack expression of NCAM. $A, B$, The same section of normal OE stained with anti-BrdU and anti-NCAM, respectively; arrows indicate BrdU $(+) / \mathrm{NCAM}(-) \mathrm{GBCs}$. $C$, The staining with GBC-1 in normal OE is confined primarily to the zone occupied by GBCs. $D$, Monoclonal antibody SUS- 4 labels sustentacular cells and cells of Bowman's glands. Single arrowheads mark the basal lamina. Magnification: $380 \times$ for $A$ and $B ; 160 \times$ for $C ; 320 \times$ for $D$.

the basal region of the $\mathrm{OE}$ at $\sim 81$ cells $/ \mathrm{mm}$ of epithelium. Approximately $25 \%$ of the total population of GBC-1 $(+)$ cells (18/mm length of epithelium) are GBCs, because they do not express neuronal- or HBC-specific markers, including the neuronal antigens NCAM and TuJ-1 or the carbohydrate moiety recognized by BS-I (Fig. 2). Indeed, most of these GBC-1 (+) GBCs [12.7/mm length of epithelium or $70 \%$ of the GBC-1 (+) GBCs] are labeled after intravenous administration of a bolus of BrdU and, hence, fulfill another criterion for classification as GBCs, namely being mitotically active (Figs. 1,3 ). The BrdU (+)/GBC-1 (+) cells are distinguishable from HBCs (which can also be mitotically active and labeled by BrdU, but at a low frequency in the normal OE) (Calof and Chikaraishi, 1989; Huard and Schwob, 1995) by their more superficial position, round shape, and lack of reactivity to any one of several markers that distinguish HBCs from other cell types in the OE (Holbrook et al., 1995), including the lectin BS-I (Fig. 2) and antibody directed against the EGF receptor (data not shown). Most of the GBC-1 (+) GBCs that do not incorporate BrdU after a single pulse of labeled nucleotide are likely to be mitotically active, although not in $\mathrm{S}$ phase at the time of BrdU administration. Indeed, one estimate of the total percentage that is proliferating can be derived from the percentage that is labeled acutely by BrdU and the duration of the $\mathrm{S}$ phase relative to the total cell cycle $\left(T_{S}=9 \mathrm{hr}, T_{C} \sim 17 \mathrm{hr}\right.$ ) (Huard and Schwob, 1995). From these kinetic parameters, we estimate that $55 \%$ of the proliferating cells are in $\mathrm{S}$ phase at any one point in time or, inversely, that $\sim 23 \mathrm{GBC}-1(+)$ cells/mm are mitotically active $(28 \%$ of the total number of GBC-1 $(+)$ cells). However, this estimate is not absolutely precise given the likelihood of circadian variation in the proliferative population (Hinds et al., 1984). Nonetheless, it seems that the vast majority of the NCAM $(-) / G B C-1(+)$ population is proliferating and that only a small percentage of the GBC-1 (+) GBCs (if any) is quiescent. About three-quarters of the GBC-1 $(+)$ cells show morphological and immunochemical evidence of neuronal differentiation, but all GBC-1 (+) neurons are found deep in the epithelium (Fig. 2). Double labeling with antibodies to GAP-43 and GBC-1 demonstrates numerous GAP-43 (+)/GBC-1 (+) neurons; indeed, GBC-1 labeling does not extend superficial to the band of GAP-43 $(+)$ cells (data not shown). Hence, we conclude that the GBC-1 $(+)$ neurons in the normal epithelium are immature. We found no examples of HBCs, sustentacular cells, or duct cells that stained with GBC-1 in normal OE (Fig. 2).

The notion that GBC-1 stains GBCs is supported further by the pattern of GBC-1 labeling of OE during the recovery from experimental injury (Fig. 4). The number of mitotically active GBCs, as defined above, increases by four- to fivefold within the first week after either bulbectomy or exposure to $\mathrm{MeBr}$ (Costanzo and 

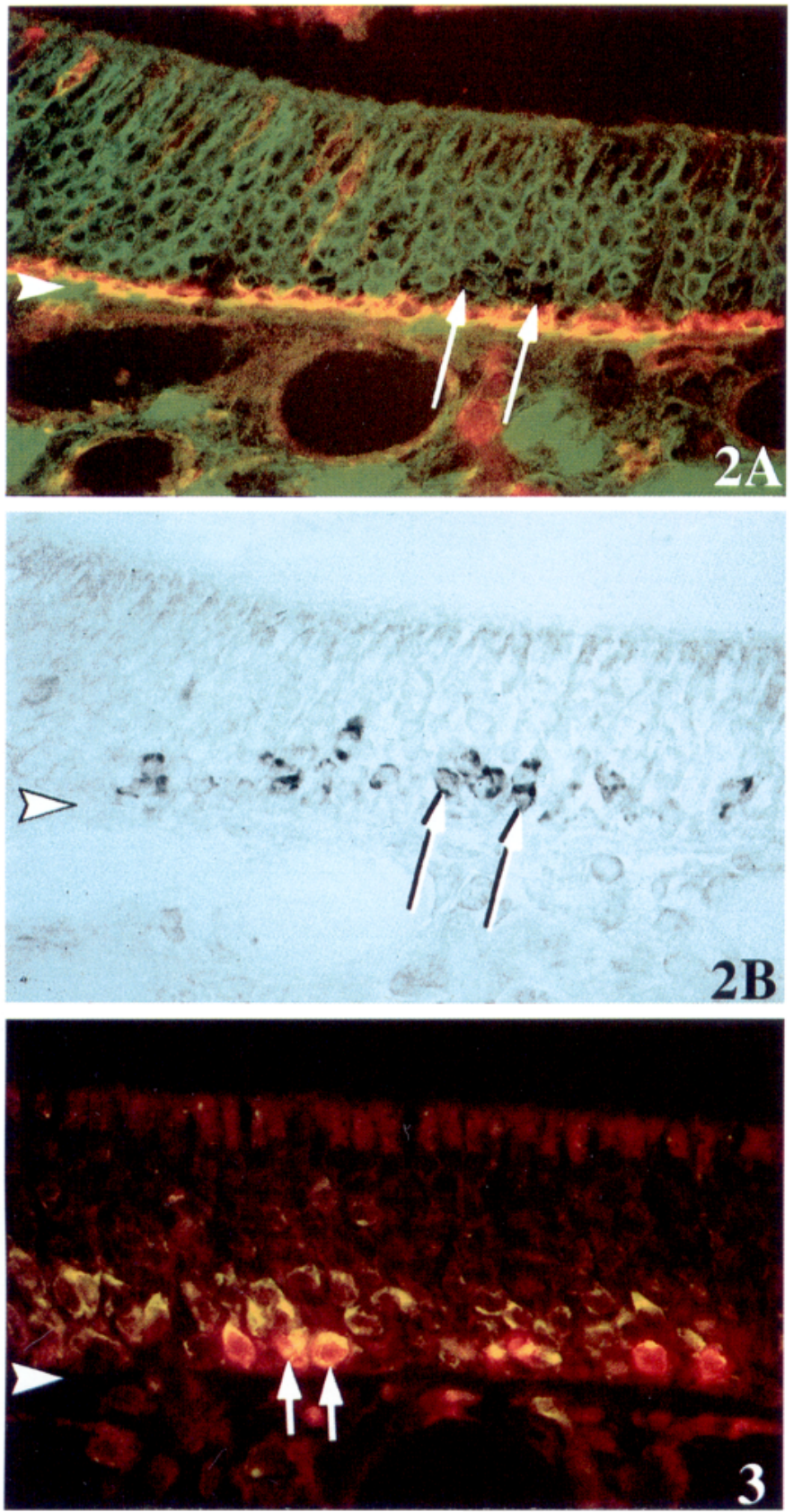

Figure 2. In normal $\mathrm{OE}, \mathrm{GBC}-1$ does not label $\mathrm{HBCs}$, and many GBC-1 $(+)$ cells are not neurons. $A, B$, A single section was stained with GBC-1 (immunoperoxidase label in $B$ ), BS-I (red fluorescence in $A$ ) to label HBCs, and anti-NCAM (green fluorescence in $A$ ) to label neurons. Examples of GBC-1-labeled basal cells are indicated by the arrows in $A$ and $B$. Comparison of $A$ and $B$ indicates some overlap between anti-NCAM and GBC-1; for example, the more superficial of the two GBC-1 $(+)$ cells above the right arrow is NCAM $(+)$. Arrowheads mark the basal lamina. Magnification, $320 \times$.

Figure 3. GBC-1 stains mitotically active cells. OE $4 \mathrm{~d}$ after bulbectomy is stained with GBC-1 (yellow-green) and anti-BrdU (red). Arrows indicate examples of GBC-1 $(+)$ cells that have incorporated BrdU. The arrowhead indicates the basal lamina. Magnification, 490×.

Graziadei, 1983; Costanzo, 1984; Verhaagen et al., 1990; Carr and Farbman, 1992; Schwob et al., 1992, 1995). Approximately paralleling the increase in proliferating $\mathrm{GBCs}$, the number of $\mathrm{GBC}-1$ $(+)$ cells increases in epithelium examined during the first week
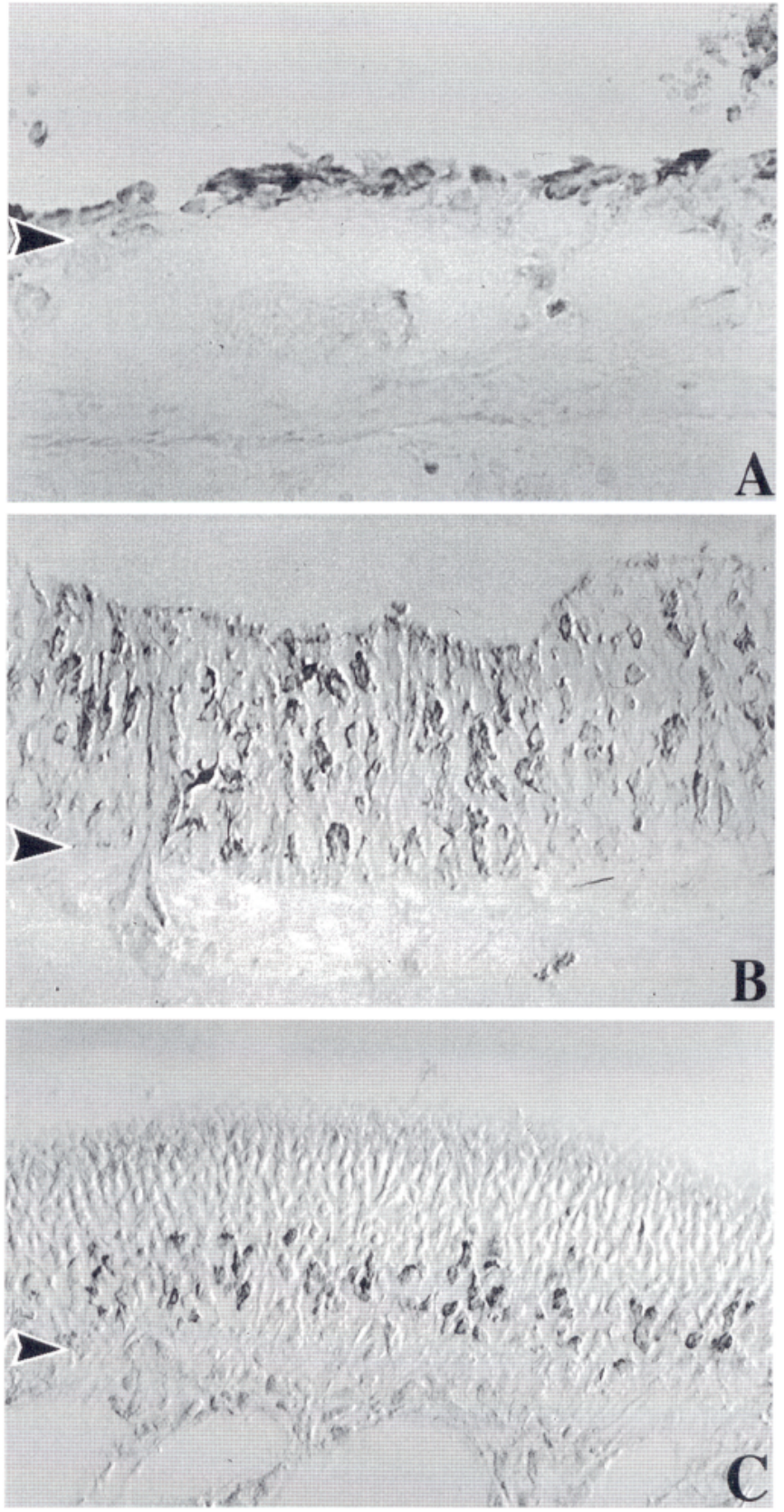

Figure 4. GBC-1 stains many cells in the OE during reconstitution after experimental injury. $A$, At $2 \mathrm{~d}$ after direct injury with $\mathrm{MeBr}$ gas. The regenerating epithelium contains a thin layer of cells, many of which are GBC-1 (+). B, At $7 \mathrm{~d}$ after $\mathrm{MeBr}$ exposure. GBC-1 staining extends through much of the height of the epithelium. $C$, At $4 \mathrm{~d}$ after olfactory bulb ablation. GBC-1 $(+)$ cells are numerous and located deep in the epithelium. The more superficially placed GBC-1 (+) cells in $B$ and $C$ are neurons (compare with Fig. 5). Arrowheads indicate the basal lamina. Magnification, $320 \times$.

after bulbectomy compared with normal (compare Figs. 1C, $4 C$ ); counts of NCAM $(-) /$ GBC- $1(+)$ cells increase $\sim 2.5$-fold from 18 per mm length of septal epithelium in normal to 41 per $\mathrm{mm}$ at 4 d after ablation. Similarly, GBC-1 (+) cells are evident in the lesioned epithelium 24-48 hr after $\mathrm{MeBr}$ exposure (Fig. 4A), which is before the reappearance of neurons (i.e., only GBCs and HBCs remain) (Schwob et al., 1995). Their number expands to markedly greater than normal during the remainder of the first week after lesion (compare Figs. $1 C, 4 B$ ), at which point the 
proliferative response has peaked (Schwob et al., 1995). For example, at $4 \mathrm{~d}$ after $\mathrm{MeBr}$ exposure, there are $\sim 112 \mathrm{NCAM}$ $(-) / G B C-1(+)$ cells/mm length of epithelium, which is a sixfold increase compared with the value in normal (cited above). Thus, both the spatial and temporal patterns of GBC- 1 immunoreactivity indicate that GBC-1 stains GBCs.

\section{GBC-1-labeled neurons are more abundant in the regenerating epithelium}

The group of cells stained with GBC-1 extends far superficial to the NCAM (-)/BS-I (-) population at times when a substantial number of immature neurons are present and mature neurons are rare (e.g., at short survivals after bulbectomy or during the early stages in the reconstitution of the epithelium after $\mathrm{MeBr}$ lesion). For example, a large population of immature [i.e., G^P-43 (+)] neurons emerges superficial to the expanded and still-increasing population of proliferating basal cells between 4 and $7 \mathrm{~d}$ after $\mathrm{MeBr}$ exposure (Schwob et al., 1995). At $7 \mathrm{~d}$ postlesion, virtually all of the neurons are immature and GAP-43 $(+)$; in fact, olfactory marker protein (OMP) (+) neurons are vanishingly rare (Schwob et al., 1995). Many of these immature neurons also stain with GBC-1, because GBC-1 (+) cells that are bipolar in shape and clearly resemble neurons are found throughout much of the height of the epithelium (Fig. $4 B$ ). However, judging by the size of the population of GBC-1 $(+)$ cells at this time, not all GAP-43 $(+)$ immature neurons stain with GBC-1 (compare Fig. $4 B$ with Fig. $9 B$ of Schwob et al., 1995). Subsequently, staining with GBC-1 progressively becomes restricted to cells deep in the epithelium as the population of immature neurons contracts to a narrow band located just superficial to the GBC compartment; this is the pattern observed in normal epithelium, as described above.

Similar results are obtained at short survivals after olfactory bulbectomy. The population of GBC-1 $(+)$ neurons is expanded after bulbectomy compared with normals and extends superficial to the GBC population to a greater extent than in normal epithelium. The vast majority of neurons is immature and GAP-43 (+) $4 \mathrm{~d}$ after bulbectomy, and only $\sim 5 \%$ of the neurons are OMP $(+)$ (J. E. Schwob, unpublished observations). Double labeling with GBC- 1 and NCAM clearly demonstrates GBC-1 (+)/NCAM $(+)$ neurons but also shows that some of these neurons are not GBC-1 (+) (Fig. 5). Furthermore, the combination of GAP-43 with GBC-1 demonstrates that GBC-1 (+) neurons are exclusively immature (data not shown), in keeping with their distribution in the epithelium (Fig. 4C) and the status of the neuronal population at this time acutely after bulb ablation. However, some of the immature neurons are not GBC-1 $(+)$ in this experimental setting (Fig. 5) (data not shown), as is true after MeBr lesion (see above).

\section{GBC-1 labels some reactive HBCs in the $\mathrm{MeBr}$-lesioned, reconstituting epithelium}

The concurrent expression of GBC-1 and neuronal markers shortly after bulbectomy or $\mathrm{MeBr}$ lesion led us to evaluate whether other immunochemically defined cell types express this marker at linited time points in the MeBr-lesioned epithelium. HBCs, identifiable by any of the several markers characteristic of this cell type (Holbrook et al., 1995), undergo a complex, poorly understood response to $\mathrm{MeBr}$ lesion (Schwob et al., 1995). In dorsomedial epithelium, marker-defined HBCs proliferate and accumulate during the acute phase of epithelial reconstitution and then regress to a monolayer of cells that are apposed tightly to the basal lamina, as is characteristic of unlesioned OE. In the ventral epithelium, they disappear during this same time frame and then later reappear. The pattern of their disappearance is not consistent with acute cell loss but instead may correspond to transdifferentiation of these cells and the loss of the marker-defined HBC phenotype (Schwob et al., 1995).

The regenerating epithelium lining the dorsal recess contains cells that stain with both GBC-1 and HBC inarkers, including BS-I lectin and anti-EGF receptor antibody. For example, we have observed GBC-1 (+)/BS-I $(+)$ cells and, in other cases, GBC-1 $(+)$ /anti-EGF receptor $(+)$ cells, in $2-\mu \mathrm{m}$-thick frozen sections (Fig. 6). Three potential forms of apparent, but artefactual, double labeling can be ruled out as an explanation for this observation. First, the thinness of these sections ensures that the doublelabeling result is not caused by the overlap of cells singly labeled with each of the markers. Second, examination of these very thin sections at high magnification eliminates close apposition of singly labeled processes as the source of the doubly labeled signal (Fig. 6). Finally, immunological cross-reactivity between the immune complex that forms around GBC-1 and reagents used during the second round of immunohistochemistry is prevented by the deposition of DAB around the GBC-1-associated complex. The isolation of the first set of reagents by the accretion of $\mathrm{DAB}$ was demonstrated by eliminating either the primary or secondary antibody during the second round of immunostaining. Under these circumstances, no further deposition of signal occurred (data not shown).

As in normal epithelium, we have yet to observe any examples of GBC-1 (+)/BS-I (+) or GBC-1 (+)/anti-EGF receptor $(+)$ cells after bulbectomy.

\section{Some GBC-1 (+) cells in the MeBr-lesioned, regenerating epithelium stain with SUS-4}

In the acutely lesioned epithelium, GBC-1 and SUS-4 react against generally distinct cell populations. During the first week after MeBr exposure, SUS-4 labels cells of Bowman's glands in the lamina propria, Bowman's gland duct cells in the epithelium, and cells flattened over the apical surface of the epithelium in proximity to labeled ducts. As reconstitution progresses, typical sustentacular cells, as defined by shape and epithelial location as well as SUS-4 reactivity, reappear, and the labeling of Bowman's glands and ducts is maintained (data not shown).

A limited number of cells in the regenerating OE are doubly labeled by both GBC-1 and SUS-4, using thin sections of the epithelium, high magnification examination, and class-specific reagents as described in Materials and Methods to rule out artefactual double labeling (Fig. 7); the GBC-1 (+)/SUS-4 (+) cells are observed at a frequency of approximately eight double-labeled cells per $3 \mu \mathrm{m}$ coronal section of the septum at 2-3 d after $\mathrm{MeBr}$ exposure. No cross-reactivity was observed when these classspecific reagents were used in experiments in which one of the other primary antibodies was eliminated, verifying that the double-labeled cells express both antigens. Nonetheless, it is worth emphasizing that most SUS-4 (+) cells are not GBC-1 (+) and vice versa. Thus, these antibodies label primarily distinct populations.

We have not yet observed any such GBC-1 (+)/SUS-4 (+) cells in normal or bulbectomized epithelium, in which SUS-4 and GBC-1 label spatially distinct cell populations (compare Figs. $1 C, D$ and $4 C$ ). Also, it is important to note that $\mathrm{GBC}-1$ reactivity is confined to cells within the epithelium, as described above, and does not stain cells in the lamina propria under any circumstances, including $\mathrm{MeBr}$-lesioned epithelium, that have been examined (Fig. 4). 

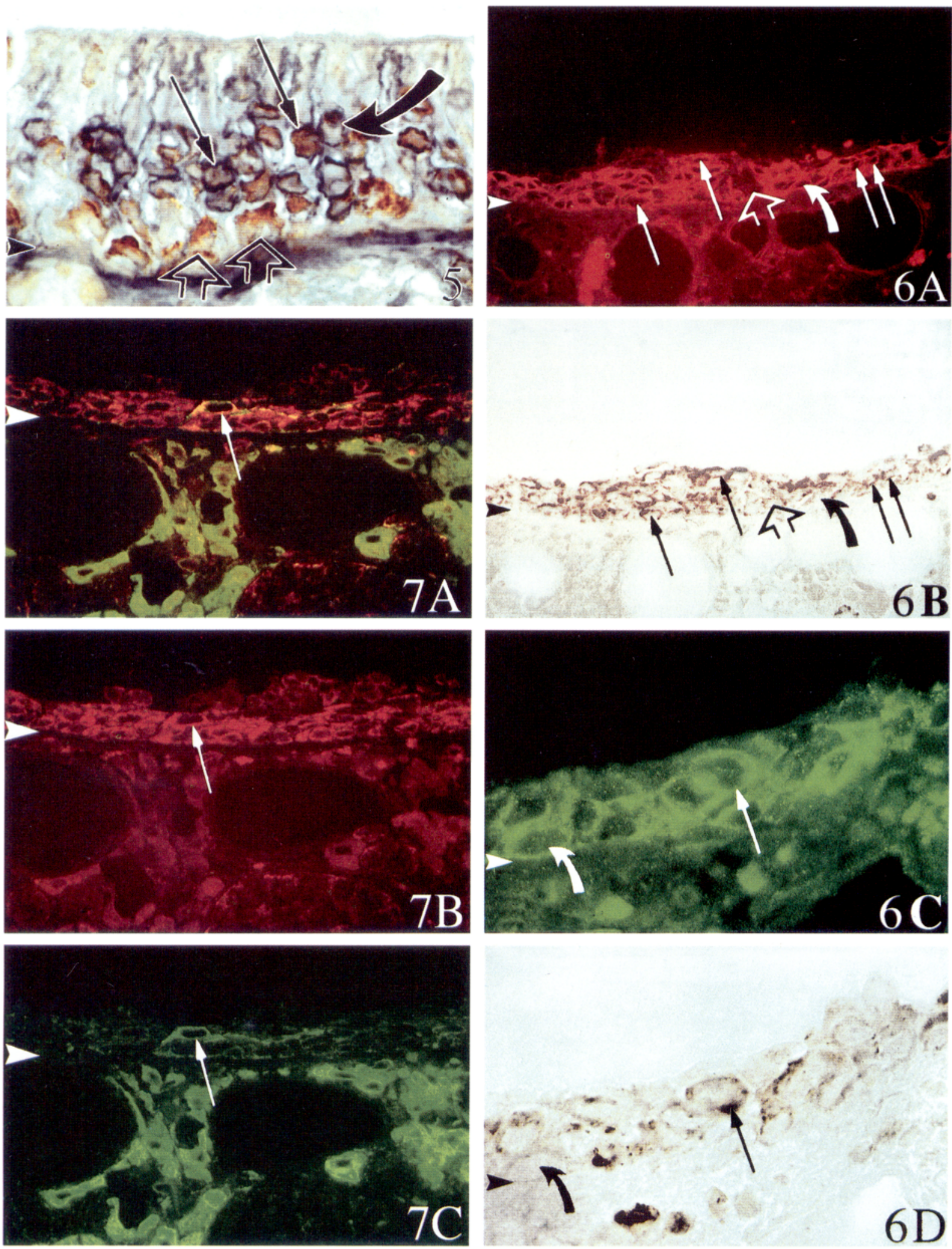

Figure 5. In addition to GBCs, GBC-1 labels some neurons. Tissue taken $4 \mathrm{~d}$ after olfactory bulb ablation, when neurogenesis is upregulated, and stained with GBC-1 (brown) and the neuronal marker anti-NCAM (blue-gray). GBC-1 (+)/NCAM (+) double-labeled cells are indicated by thin arrows. Short open arrows designate examples of cells labeled only by GBC-1, whereas the curved arrow indicates a cell labeled only by anti-NCAM. Arrowhead indicates the basal lamina. Magnification, $565 \times$.

Figure 6. In the regenerating $\mathrm{OE}$, some $\mathrm{GBC}-1(+)$ cells are labeled also by $\mathrm{HBC}$-specific markers. $A-D$, Some $2-\mu \mathrm{m}$-thick sections taken from dorsal $\mathrm{OE} 2 \mathrm{~d}$ after MeBr-induced lesion. $A, B$, Single section stained with the HBC-specific marker BS-I (red fluorescence in $A$ ) and with GBC-1 (brown peroxidase product in $B$ ). $C, D$, Single section stained with the HBC-specific marker anti-epidermal growth factor receptor (green fluorescence in $C$ ) and 


\section{GBC-1 (-) GBCs are also present within the basal cell compartment}

As conventionally defined, any cell in the normal or regenerating OE that is not a neuron, $\mathrm{HBC}$, or supporting cell (i.e., fails to express neuronal, HBC, or sustentacular cell markers) and resides near the basal lamina is said to be a GBC (Schwob, 1992). However, defining a category by the absence of staining with identified markers does not necessarily imply biochemical or functional homogeneity within the cellular compartment. To assay for heterogeneity within the population of conventionally defined $\mathrm{GBCs}$, we examined the normal and regenerating epithelium for the presence of both GBC-1 (-) and GBC-1 (+) cells with a non-neuronal, non-HBC, nonsustentacular cell phenotype.

For example, neurons have yet to reappear anywhere in the MeBr-lesioned epithelium by $2 \mathrm{~d}$ after exposure, and $\mathrm{HBCs}$ also have disappeared from the ventral and lateral regions of the epithelium either by death or by transdifferentiation into cells that no longer express the usual HBC markers (Schwob et al., 1995). Therefore, the remaining epithelial cells in these specific regions are classifiable as either GBCs or sustentacular cells using the conventional criteria described in the introductory remarks. Accordingly, the immunochemical phenotypes of cells in the epithelium lining the ventral septum were assessed by combining GBC-1 and SUS-4 in double immunofluorescent staining of the same section using class-specific secondary antibodies to visualize the two markers (Fig. $8 A-D$ ). In this case, a substantial number of the cells were not labeled by either marker, although their nuclei are identifiable by bis-benzimide staining. We, at this time, confirmed the previously reported absence of neurons and HBCs after lesion (Schwob et al., 1995) by staining the adjacent tissue section with a combination of BS-I lectin and anti-NCAM antibody. As expected, there was no epithelial staining with these cell-specific markers, indicating that the cells that lack reactivity with SUS-4 are GBCs (Fig. 8E,F).

Likewise, OE harvested early in its regeneration after bulb ablation also housed GBC-1 (-) GBCs (Fig. 9). In this case, the $O E$ retained its laminar organization of basal cell, neuronal, and supporting cell perikarya in order from deep to superficial, although the neuronal population had been depleted severely by retrograde degencration. Thus, staining with anti-NCAM and TuJ-1 to identify remaining and newly born neurons and with BS-I to identify $\mathrm{HBC}$ was combined with GBC-1 labeling on the same section. Some of the cells that reside in the basal region of the epithelium on the ablated side did not stain with any of these markers (Fig. 9). As a result, we classified these as GBC-1 (-) GBCs. It is important to note that the population of $\mathrm{GBC}-1(-)$ cells was less prominent here than in the MeBr-lesioned epithelium.

Thus, by combining GBC-1 and other cell-specific markers, we have determined that GBC-1 does not label all GBCs in the regenerating $\mathrm{OE}$ as they are currently defined (Figs. 8,9). In other words, the cells of the GBC compartment are heterogeneous with respect to expression of the GBC- 1 antigen during the epithelial reconstitution that follows $\mathrm{MeBr}$ lesion or olfactory bulb ablation. It is difficult to identify GBC-1 (-) cells in the globose compartment of normal, unlesioned epithelium in this manner. However, GBC-1 (-) GBCs are present in low numbers in the normal OE and can be revealed by comparing GBC-1 expression and BrdU labeling. Using this method, $\sim 20 \%$ of the BrdU ( + ) basal cells lack demonstrable GBC-1 staining (data not shown). The functional significance of this heterogeneity in the GBC population and its apparent prominence in regenerating epithelium remains to be determined.

\section{The nature of the GBC-1 antigen}

GBC-1 labeling is associated with the plasmalemma of the stained cells (Figs. 1, 6, 7). However, the subcellular distribution of the antigen, although consistent with cell surface expression, is insufficient by itself to establish that the antigen is exposed to the extracellular environment. The nature of the antigen recognized by $\mathrm{GBC}-1$ also remains primarily undefined. Staining is blocked by including nonfat milk or a cocktail of simple sugars with the primary antibody or by pretreating the sections with ethanol. That staining is obliterated with these manipulations is characteristic of glycolipid antigens (Suchy et al., 1988), suggesting that the GBC-1 antigen is a glycolipid.

\section{DISCUSSION}

The results presented here describe the generation of a monoclonal antibody GBC-1, which labels cells in the GBC compartment, and its use to characterize this population further. In the pattern of its staining of normal OE, GBC-1 resembles somewhat the monoclonal antibodies 6B7 (Akeson and Haines, 1989), BCL-1, and BCL-2 (Hempstead and Morgan, 1985), all of which apparently stain basal cells, although the published analyses do not demonstrate directly that these other antibodies label proliferating GBCs. In contrast, we have shown here that GBC-1 does label proliferating GBCs. The current studies using this new reagent provide evidence for both heterogeneity and multipotentiality within the GBC compartment.

The pattern of cellular labeling produced by GBC-1 varies substantially between normal and lesioncd cpithclium, and the differences in the staining parallel the differences in the lineage relationships and cellular dynamics in the epithelium under these conditions. For example, GBC-1 labeling in normal epithelium is confined to GBCs and some of the immature olfactory neurons, which we have classified as immature based on their morphology, position in the epithelium, and GAP-43 staining. Most of the GBC-1 (+) GBCs proliferate actively, based on an extrapolation from the number of GBC-1 (+) GBCs that are labeled with a single pulse injection of BrdU. The expansion of the pools of both GBC-1 (+) GBCs and of GBC-1 (+) neurons in response to olfactory bulb ablation parallels the increases in the rates of $\mathrm{GBC}$ proliferation and of neuronal production that occur after bulbec-

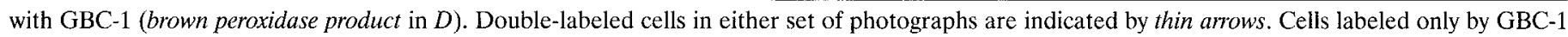

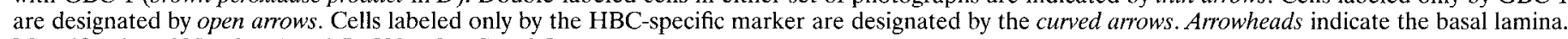
Magnification: $305 \times$ for $A$ and $B ; 580 \times$ for $C$ and $D$.

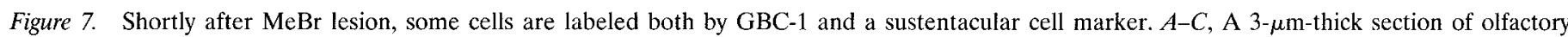

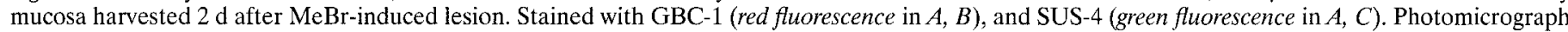

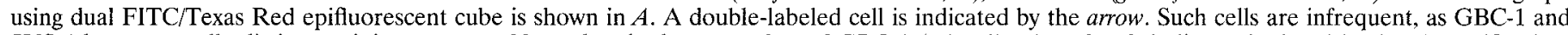

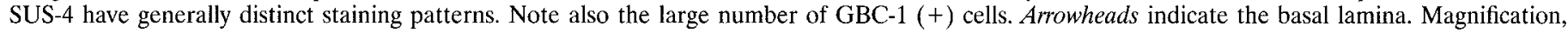
$305 \times$. 

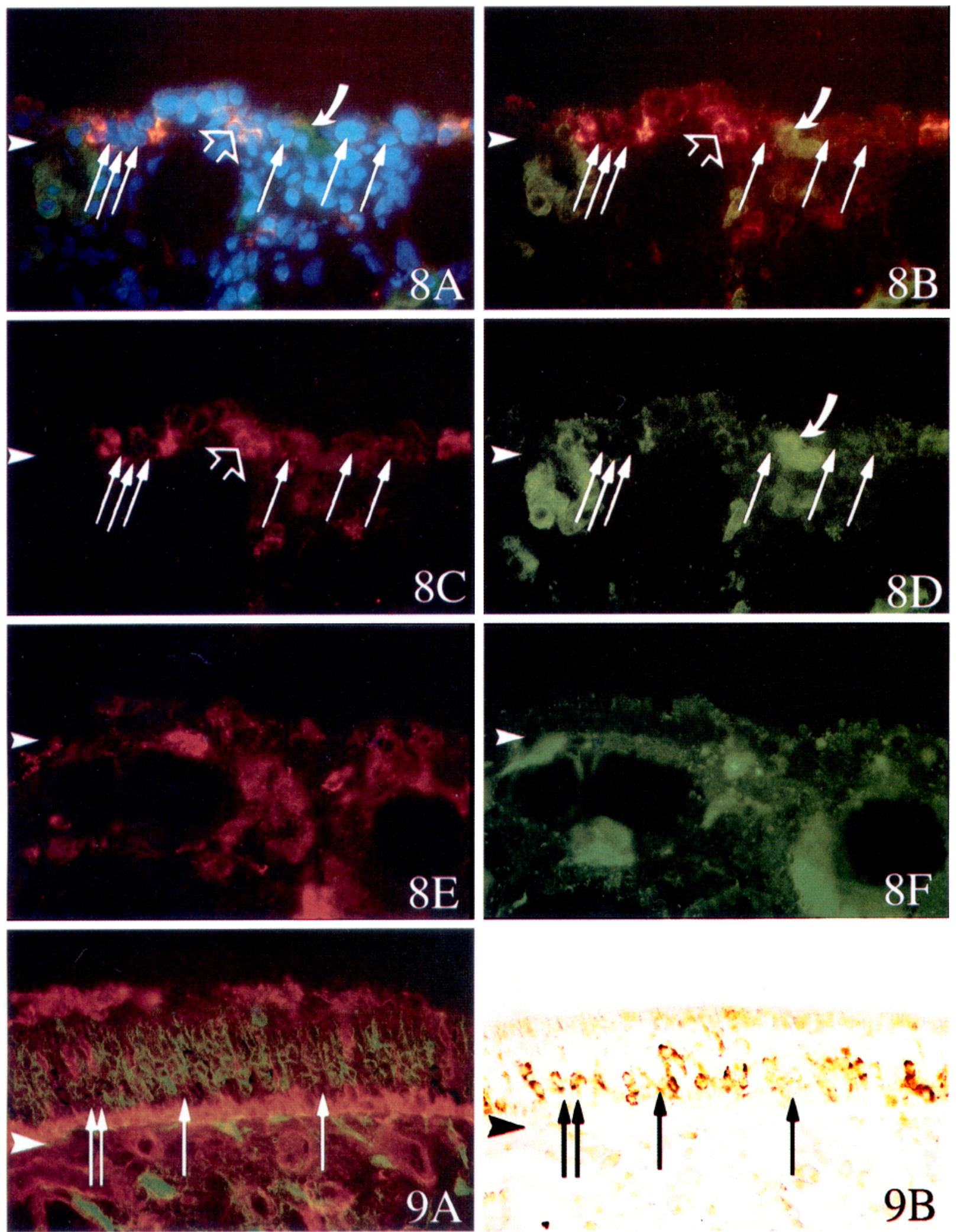

Figure 8. GBC-1 (-) globose cells are found in MeBr-lesioned and regenerating $\mathrm{OE} . A-D, \mathrm{~A} 3-\mu \mathrm{m}$-thick section harvested from ventral $\mathrm{OE} 2 \mathrm{~d}$ after $\mathrm{MeBr}$-induced lesion. Stained with GBC-1 (red fluorescence in $A-C$ ), SUS-4 (green fluorescence in $A, B, D$ ), and the general nuclear stain bis-benzimide (blue fluorescence in $A$ ). Photomicrograph using dual FITC/Texas Red epifluorescent filter set is shown in $B$. Double exposure with the dual cube and a UV cube is shown in $A$. The open arrow designates an example of a GBC-1 $(+)$ cell. The curved arrow marks a SUS-4 $(+)$ cell. Thin arrows indicate nuclei of cells that are not labeled by either marker. $E, F$, Adjacent section stained with BS-I and anti-NCAM, respectively. No cells in this area of the epithelium are labeled with either the HBC $(E)$ or neuronal marker $(F)$. The SUS-4 $(-)$ /NCAM $(-)$ /BS-I $(-)$ population is classified as GBCs and is heterogeneous with respect to expression of the GBC-1 antigen. Arrowheads indicate the basal lamina. Magnification, $340 \times$. 


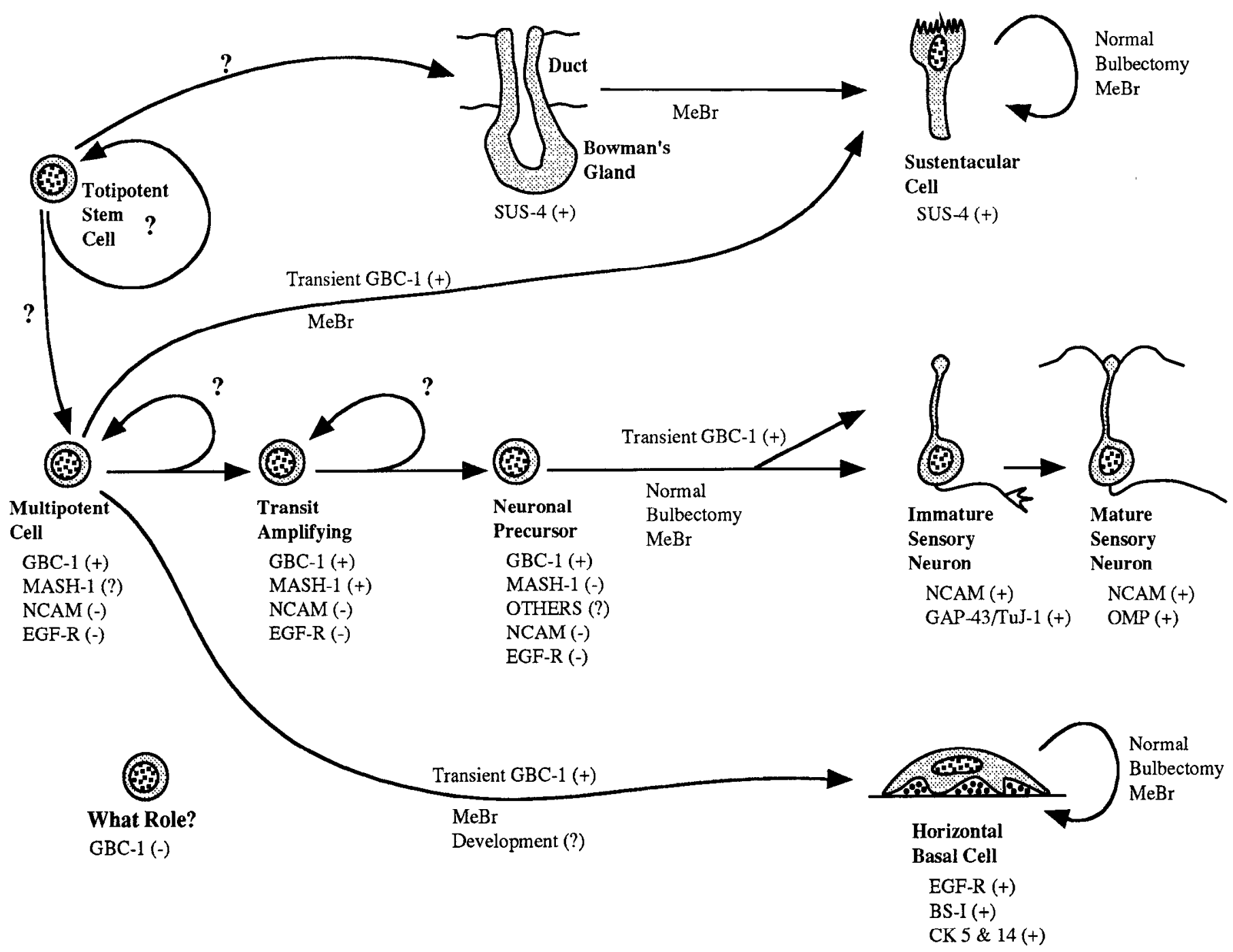

Figure 10. A working model of lineage relationships among cell types in the $\mathrm{OE}$ and their definition by the expression of biochemical markers based on the data presented here and the published literature (Graziadei and Monti Graziadei, 1979; Calof and Chikaraishi, 1989; Verhaagen et al., 1990; Schwartz Levey et al., 1991, 1992; Schwob, 1992; Schwob et al., 1992, 1994a, 1995; Caggiano et al., 1994; DeHammer et al., 1994; Gordon et al., 1995; Holbrook et al., 1995).

tomy (Verhaagen et al., 1989; Schwartz Levey et al., 1991; Carr and Farbman, 1992; Schwob et al., 1992). Likewise, a large number of GBC-1 $(+)$ neurons are observed in MeBr-lesioned and reconstituting epithelium during the first few days after the production of neurons resumes. Their number falls as the rate of production of immature neurons falls as the neuronal population is restored.

That neuronal expression of $\mathrm{GBC}-1$ is limited to immature neurons in all three settings (normal, bulbectomized, and $\mathrm{MeBr}$ lesioned epithelium) suggests that ncuronal cxprcssion of GBC-1 represents carryover of the antigen from a predecessor cell to its progeny. This expression is consistent with the wealth of evidence indicating that GBCs give rise to olfactory neurons in these settings (Fig. 10), including anatomical and tritiated thymidine studies (Moulton et al., 1970; Graziadei and Monti Graziadei,
1979; Schwartz Levey et al., 1992), in vitro studies (Calof and Chikaraishi, 1989; DeHammer et al., 1994), and lineage analyses using retrovirally derived vectors that encode marker enzymes (Caggiano et al., 1994; Schwob et al., 1994a). The carryover of GBC-1 staining from GBCs to immature neurons is explainable either by the continued synthesis of the GBC- 1 antigen as the daughter cells generated by the GBCs begin to differentiate into neurons, or by the persistence of the antigen without any new synthesis for a period of time after neuronal differentiation begins. The pcriod of this carryover must be limited, bccause mature neurons are not stained with GBC-1 and because the number of GBC-1 (+) immature neurons is also smaller than the total number of immature neurons in all of these settings. The expression of a marker antigen by a founder cell and its immediate, phenotypically distinct progeny is typical of cellular differentiation

Figure 9. GBC-1 (-) GBCs are present in OE $4 \mathrm{~d}$ after bulbectomy, when neurogenesis is upregulated. $A, B$, A section stained with GBC-1 (brown in $B$ ), anti-NCAM, and TuJ-1 to mark neurons (green fiuorescence in $A$ ) and BS-I to mark HBCs (red fiuorescence in $A$ ). Note the large number of GBC-1 $(+)$ cells. Arrows designate basal cells that are stained by none of the markers. Arrowheads indicate the basal lamina. Magnification, 320x. 
in the hematopoietic system (Spangrude, 1989; Heimfeld and Weissman, 1991) and in the developing sympathoadrenal and enteric nervous systems, which are the best characterized neuronal populations to date (Anderson et al., 1991; Blaugrund et al., 1996).

Perhaps the most novel finding to emerge from this analysis pertains to the pattern of labeling in epithelium that is reconstituting after neurons, supporting cells, and some basal cells are destroyed by exposure to MeBr (Schwob et al., 1995). During the first $24-48 \mathrm{hr}$ after the lesion, most of the cells that remain in the epithelium have the characteristics of GBCs (as conventionally defined), namely, proliferating cells lacking the markers that characterize other, better-described cell types (Schwob et al., 1995), and many of the cells in the epithelium are labeled by GBC-1 at this time. Nonctheless, some of these GBC-1 (+) cells coexpress other defined markers. For example, during the early phase in the reconstitution of the epithelium (i.e., the first week) (Schwob et al., 1995), we have observed cells that jointly express GBC-1 and HBC markers and ones that express GBC-1 and a sustentacular cell marker, in addition to the cells that express GBC-1 and neuronal markers (which we discussed above). In each of these types, the cells expressing GBC-1 and dnother non-GBC marker have the shape and disposition appropriate to the non-GBC cell type expressing that marker. In other words, cells labeled with GBC-1 and the HBC marker BS-I look like other HBCs in the epithelium at that time. We interpret the coexpression of $\mathrm{GBC}-1$ and a non-GBC marker as a sign of an early stage in the differentiation of GBCs into that other cell type; in the case of neurons expressing GBC-1 and neuronal markers, this interpretation is supported by the wealth of existing data, including lineage studies, demonstrating the descent of neurons from GBCs. Thus, the coexpression of GBC-1 and HBC-specific or sustentacular cellspecific markers after $\mathrm{MeBr}$ lesion also may reflect a lineage relationship during the reconstitution of the epithelium among GBCs on one hand and HBCs and sustentacular cells on the other (Fig. 10).

Evidence supports the notion that GBCs, HBCs, neurons, and sustentacular cells all are related lineally during reconstitution of the MeBr-lesioned epithelium. The infusion of a replicationincompetent retrovirus that encodes a heritable marker enzyme into the nasal cavity of an $\mathrm{MeBr}$-lesioned and recovering rat produces clusters of virally marked cells in the OE that contain HBCs, neurons, sustentacular cells, and GBCs within a single cluster (Schwob et al., 1994a). Aspects of these data, including the finding that a single type of enzyme is expressed homogeneously within a cluster when two different retroviral vectors bearing phenotypically different marker enzymes are infused together, indicate that the virally marked clusters are likely to derive from a single founder cell; i.e., they are likely to be clonal (Schwob et al, 1994a). Thus, MeBr lesion in some manner activates or unveils the persistence of multipotent cells within the adult $\mathrm{OE}$ that are capable of ultimately giving rise to neurons, GBCs, HBCs, and sustentacular cells (Fig. 10). Given the sparing of basal cells with the $\mathrm{MeBr}$-induced lesion and the lack of clusters that contain neurons and cells of either Bowman's glands or ducts, these multipotent cells are likely to reside in the basal cell compartment (Fig. 10) (Schwob et al., 1994a).

Some additional correlative evidence suggests that GBCs can give rise to HBCs in addition to neurons. For example, during the reconstitution of ventrolateral $\mathrm{OE}$ that follows $\mathrm{MeBr}$ exposure, HBC's reappear in situ, in spatial proximity to the GBCs, and do not migrate into the epithelium from areas in which HBCs are retained (Schwob et al., 1995). These data do not completely exclude the possibility that the HBCs derive from non-GBC cells that migrate from superficial to deep through the basal cell compartment to take up residence in apposition to the basal lamina. However, the lineage relationship between HBCs and GBCs is also supported by data from experiments in which mice were made homozygous for a null mutation of the mammalian achaete-scute homolog-1 (Mash-1) gene (Guillemot et al., 1993). That the OE of Mash-1 knock-out mice reportedly is missing most of its usual complement of GBCs, neurons, and HBCs but is not lacking Bowman's glands, ducts, and supporting cells has been interpreted as support for the suggestion that these cell types are related lineally during development (Guillemot et al., 1993); however, alternative explanations, such as a trophic dependence of HBCs on these other cell types, cannot be completely ruled out. That HBCs appear after GBCs and neurons in normal embryos is not inconsistent with the suggestion of a lineage relationship among these cells during development (Suzuki and Takeda, 1991; Holbrook et al., 1995), but suggests that the likely direction of that relationship is from $\mathrm{GBC}$ to $\mathrm{HBC}$, rather than the reverse (Fig. 10).

Likewise, some correlative evidence in addition to the lineage studies cited above supports the suggestion that some sustentacular cells derive from GBCs during epithelial regeneration and that this relationship accounts for the cells in the MeBr-lesioned and regenerating $\mathrm{OE}$ that are immunoreactive for both GBC-1 and SUS-4. The finding that some sustentacular cells reappear early in the regeneration of the epithelium at a distance from the ducts of Bowman's glands (the other source for sustentacular cells during epithelial reconstitution, based on lineage and other studies) (Schwob et al., 1994a, 1995) (Fig. 10) suggests that these sustentacular cells derive from some nonduct source. [The low frequency of GBC-1 (+)/SUS-4 (+) cells may partially reflect the alternative derivation of sustentacular cells from the spared ducts of Bowman's glands, as well as a limited period of carryover of the antigen during differentiation of sustentacular cells from GBCs.] That sustentacular cells are retained and increased in Mash-1 null homozygotes is consistent with, but does not compel, the interpretation that $\mathrm{OE}$ progenitors can be diverted to a sustentacular cell phenotype in the absence of Mash-1 (Guillemot et al., 1993).

In contrast to epithelial reconstitution, sustentacular cells apparently self-replicate in normal epithelium (Graziadei and Monti Graziadei, 1979), which can account for the absence of GBC-1 $(+)$ /SUS-4 $(+)$ cells in normal and bulbectomized epithelium.

The evidence cited above for a lineage relationship among GBCs, HBCs, sustentacular cells, and neurons via the activation of multipotent cells during $\mathrm{MeBr}$-induced epithelial reconstitution, the sparing of basal cells after MeBr lesion (Schwob et al., 1995), the staining of many of them with GBC-1 at 1-2 d after lesion when multipotent cells are demonstrable in the reconstituting epithelium (Schwob et al., 1994a), and the present finding that some cells coexpress GBC-1 and lineage-specific markers leads us to suggest the following testable hypothesis. We propose that multipotent cells capable of giving rise to GBCs, HBCs, sustentacular cells, and neurons express the GBC-1 antigen (Fig. 10). Furthermore, we suggest that the GBC-1 antigen is retained during early stages of the commitment and differentiation of precursor cells into HBCs, neurons, or GBC-derived sustentacular cells during the reconstitution of the epithelium after injury.

In contrast to their apparent potential to differentiate into multiple cell types during the epithelial reconstitution that follows $\mathrm{MeBr}$ exposure, GBCs in the normal and bulb-ablated epithelium, 
which necessarily must include GBC-1 (+) GBCs, apparently give rise only to neurons and GBCs (Schwartz Levey et al., 1991, 1992; Caggiano et al., 1994; Schwob et al., 1994a). As a consequence, the proliferating GBCs in normal or bulbectomized epithelium are mainly, if not exclusively, transit-amplifying and committed neuronal precursor cells rather than stem or multipotent cells. The apparent preponderance of transit-amplifying cells or committed neuronal precursors in normal and bulbectomized epithelium implies that the multipotent cells observed after $\mathrm{MeBr}$ lesion are absent or quiescent when the epithelium is replenishing only neurons. More recently, immunohistochemical studies of MASH-1 protein in the adult and developing OE suggest that MASH-1 is expressed by a subset of proliferating GBCs (Gordon et al., 1995). The characteristics of its expression both in vivo and in vitro have led to the suggestion that $\mathrm{M} \wedge \mathrm{SH}-1$ is found in transit-amplifying cells (Gordon et al., 1995). Interestingly, we have obtained preliminary data using other, newly generated monoclonal antibodies from our laboratory that suggest an immunochemically distinct subpopulation of GBC-1 $(+)$ cells are committed neuronal precursors that appear at a later stage in the reconstitution of the $\mathrm{MeBr}-\mathrm{lesioned}$ epithelium.

The presence of the GBC- 1 antigen on GBCs that apparently are committed neuronal precursors, i.e., the GBCs of normal or bulbectomized epithelium, may represent the continued expression of the antigen in cells that are functionally different from the GBC-1 (+) cells in MeBr-lesioned epithelium. Alternatively, the apparent functional heterogeneity of GBC-1 (+) cells among the various experimental conditions may reflect alterations in the regulatory signals operating in the epithelium in normal versus bulb-ablated versus $\mathrm{MeBr}-\mathrm{lesioned}$ epithelium. These alternatives can be evaluated by putting cells from normal or bulbectomized epithelium into $\mathrm{MeBr}$ lesioned epithelium and vice versa.

In addition to the observations of GBC-1 (+) cells in the basal cell compartment, we also noted other GBCs (defined as nonHBC, non-neuronal, and nonsustentacular cells) that do not stain with GBC-1. They were found in normal OE and in epithelium that is recovering after either $\mathrm{MeBr}$-induced lesion or bulbectomy. The identification of GBC-1 (-) GBCs depends on a negative immunohistochemical result and, hence, must be interpreted with some caution. For example, it is known that macrophages and other inflammatory cells enter the epithelium under some conditions (Monti Graziadei and Graziadei, 1979; Mellert et al., 1992; Suzuki et al., 1995). However, the number of these GBC-1(-) GBCs is heterogeneous across the epithelium and can be quite high in some places (like that illustrated in Fig. 8) in which it exceeds the number of macrophages that can be identified in the $\mathrm{MeBr}$-lesioned epithelium on the basis of the binding of $\mathrm{Ig}$ via its Fc portion (B. J. Goldstein and J. E. Schwob, unpublished observations) or in bulbectomized animals on the basis of macrophage markers (Suzuki et al., 1995). Thus, the result suggests additional heterogeneity within the GBC compartment that may be functionally significant, given the prominence of these cells in lesioned compared with normal epithelium.

It will be important to compare the expression of the GBC-1 antigen and the other globose cell markers with that of MASH-1 (Gordon et al., 1995) and with functional assays of the capacity of GBCs to differentiate into various cell types to elucidate further the subpopulations within the GBCs. Studies of that nature likely will prove useful in defining a lineage tree that is more explicit and less riddled with unanswered questions than is currently possible for precursor cell-daughter cell relationships in the $\mathrm{OE}$ and their patterns of marker expression (Fig. 10).

\section{REFERENCES}

Akeson RA, Haines SL (1989) Rat olfactory cells and a central nervous system neuronal subpopulation share a cell surface antigen. Brain Res 488:202-212.

Anderson DJ, Carnahan JF, Michelsohn A, Patterson PH (1991) Antibody markers identify a common progenitor to sympathetic neurons and chromaffin cells in vivo and reveal the timing of commitment to neuronal differentiation in the sympathoadrenal lineage. J Neurosci 11:3507-3519.

Blaugrund E, Pham TD, Tennyson VM, Lo L, Sommer L, Anderson DJ, Gershon MD (1996) Distinct subpopulations of enteric neuronal progenitors defined by time of development, sympathoadrenal lineage markers and Mash-1 dependence. Development 122:309-320.

Caggiano M, Kauer JS, Hunter DD (1994) Globose basal cells are neuronal progenitors in the olfactory epithelium: a lineage analysis using a replication-incompetent retrovirus. Neuron 13:339-352.

Calof AL, Chikaraishi DM (1989) Analysis of neurogenesis in a mammalian neuroepithelium: proliferation and differentiation of an olfac tory neuron precursor in vitro. Neuron 3:115-127.

Carr VMcM, Farbman AI (1992) Ablation of the olfactory bulb upregulates the ratc of ncurogencsis and induces precocious cell death in olfactory epithelium. Exp Neurol 115:55-59.

Costanzo RM (1984) Comparison of neurogenesis and cell replacement in the hamster olfactory system with and without a target (olfactory bulb). Brain Res 307:295-301.

Costanzo RM, Graziadei PPC (1983) A quantitative analysis of changes in the olfactory epithelium following bulbectomy in hamster. $\mathrm{J}$ Comp Neurol 215:370-381.

Covault J, Sanes JR (1986) Distribution of N-CAM in synaptic and extrasynaptic portions of developing and adult skeletal muscle. J Cell Biol 102:716-730.

DeHammer MK, Guevara JL, Hannon K, Olwin BB, Calof AL (1994) Genesis of olfactory receptor neurons in vitro: regulation of progenitor cell divisions by fibroblast growth factors. Neuron 13:1083-1097.

Gordon MK, Mumm JS, Davis RA, Holcomb JD, Calof AL (1995) Dynamics of MASH1 expression in vitro and in vivo suggest a non-stem cell site of MASH1 action in the olfactory receptor neuron lineage. Mol Cell Neurosci 6:363-379.

Graziadei PPC, Monti Graziadei GA (1979) Neurogenesis and neuron regeneration in the olfactory system of mammals. I. Morphological aspects of differentiation and structural organization of the olfactory sensory neurons. J Neurocytol 8:1-18.

Guillemot F, Lo L-C, Johnson JE, Auerbach A, Anderson DJ, Joyner AL (1993) Mammalian achaete-scute homolog 1 is required for the early development of olfactory and autonomic neurons. Cell 75:463-476.

Harlow E, Lane D (1988) Antibodies: a laboratory manual, pp 139-244. Cold Spring Harbor, NY: Cold Spring Harbor.

Heimfeld S, Weissman IL (1991) Development of mouse hematopoictic lineages. Curr Top Dev Biol 25:155-175.

Hempstead JL, Morgan JI (1985) A panel of monoclonal antibodies to the rat olfactory epithelium. $J$ Neurosci 5:438-449.

Hinds JW, Hinds PL, McNelly NA (1984) An autoradiographic study of the mouse olfactory epithelium: evidence for long-lived receptors. Anat Rec 210:375-383.

Holbrook EH, Mieleszko Szumowski KE, Schwob JE (1995) An immunochemical, ultrastructural and developmental characterization of the horizontal basal cells of rat olfactory epithelium. J Comp Neurol 363:129-146.

Huard JMT, Schwob JE (1995) Cell cycle of globose basal cells in ral olfactory epithelium. Dev Dyn 203:17-26.

Lee VM, Pixley SK (1994) Age and differentiation-related differences in neuron-specific tubulin immunostaining of olfactory sensory neurons. Dev Brain Res 83:209-215.

Meiri KF, Bickerstaff LE, Schwob JE (1991) Monoclonal antibodies show that kinase $\mathrm{C}$ phosphorylation of GAP-43 during axonogenesis is both spatially and temporally restricted in vivo. J Cell Biol 112:991 1005

Mellert TK, Getchell ML, Sparks L, Getchell TV (1992) Characterization of the immune barrier in human olfactory mucosa. Otolaryngol Head Neck Surg 106:181-188.

Monti Graziadei GA, Graziadei PPC (1979) Neurogenesis and neuron regeneration in the olfactory system of mammals. II. Degeneration and reconstitution of the olfactory sensory neurons after axotomy. J Neurocytol 8:197-213. 
Moody SA, Quigg MS, Frankfurter A (1987) Development of the peripheral trigeminal system in the chick revealed by an isotype-specific anti-beta-tubulin monoclonal antibody. J Comp Neurol 279:567-580.

Morris RJ, Potten CS (1994) Slowly cycling (label-retaining) epidermal cells behave like clonogenic stem cells in vitro. Cell Prolif 27:279-289.

Moulton DG, Celebi G, Fink RP (1970) Olfaction in mammals-two aspects: proliferation of cells in the olfactory epithelium and sensitivity to odours. In: Taste and smell in vertebrates (Wolstenhome GEW, Knight J, eds), pp 227-250. London: Churchill.

Potten CS, Hendry JH (1983) Stem cells in murine small intestine. In: Stem cells: their identification and characterization (Potten CS, ed), pp 155-199. Edinburgh: Churchill Livingstone.

Schultz EW (1941) Regeneration of olfactory cells. Proc Soc Exp Biol Med 46:41-43.

Schwartz Levey MA, Chikaraishi DM, Kauer JS (1991) Characterization of potential precursor populations in the mouse olfactory epithelium using immunocytochemistry and autoradiography. J Neurosci $11: 3556-3564$.

Schwartz Levey MA, Cinelli AR, Kauer JS (1992) Intracellular injection of vital dyes into single cells in the salamander olfactory epithelium. Neurosci Lett 140:265-269.

Schwob JE (1992) The biochemistry of olfactory neurons: stages of differentiation and neuronal subsets. In: Science of olfaction (Serby ML, Chodor KL, eds), pp 80-125. New York: Springer.

Schwob JE, Mieleszko Szumowski KE, Stasky AA (1992) Olfactory sensory neurons are trophically dependent on the olfactory bulb for their prolonged survival. J Neurosci 12:3896-3919.
Schwob JE, Huard JMT, Luskin MB, Youngentob SL (1994a) Retroviral lineage studies of the rat olfactory epithelium. Chem Senses 19:671-682.

Schwob JE, Youngentob SL, Meiri KF (1994b) On the formation of neuromata in the peripheral olfactory system. J Comp Neurol 340:361-380.

Schwob JE, Youngentob SL, Mezza RC (1995) Reconstitution of the rat olfactory epithelium after methyl bromide-induced lesion. J Comp Neurol 359:15-37.

Spangrude GL (1989) Enrichment of murine haemopoietic stem cells: diverging roads. Immunol Today 10:344-350.

Suchy SF, Yamamoto MY, Barbero L, Schwarting GA (1988) A monoclonal antibody, WCC4, recognizes a developmentally regulated ganglioside containing $\alpha$-galactose and $\alpha$-fucose present in the rat nervous system. Brain Res 440:25-34.

Suzuki Y, Takeda M (1991) Basal cells in the mouse olfactory epithelium after axotomy: immunohistochemical and electron-microscopic studies. Cell Tissue Res 266:239-245.

Suzuki Y, Schafer J, Farbman AI (1995) Phagocytic cells in the rat olfactory epithelium after bulbectomy. Exp Neurol 136:225-233.

Verhaagen J, Oestreicher AB, Grillo M, Khew-Goodall Y-S, Gispen WH, Margolis FL (1990) Neuroplasticity in the olfactory system: differential effects of central and peripheral lesions of the primary olfactory pathway on the expression of B-50/GAP43 and the olfactory marker protein. J Neurosci Res 26:31-44. 